Article

\title{
Living Mulch Management Spatially Localizes Nutrient Cycling in Organic Corn Production
}

\author{
Peyton Ginakes ${ }^{1}$, Julie M. Grossman ${ }^{2, * \mathbb{C}}$, John M. Baker ${ }^{3,4}$ and Thanwalee Sooksa-nguan ${ }^{5}$ \\ 1 School of Food and Agriculture, University of Maine, Orono, ME 04473, USA; peyton.ginakes@maine.edu \\ 2 Department of Horticultural Science, University of Minnesota, St. Paul, MN 55108, USA \\ 3 Soil and Water Management Research Unit, USDA-ARS, St. Paul, MN 55108, USA; jbaker@umn.edu \\ 4 Department of Soil, Water, and Climate, University of Minnesota, St. Paul, MN 55108, USA \\ 5 Department of Agricultural and Biosystems Engineering, Iowa State University, Ames, IA 50011, USA; \\ tsjijy@iastate.edu \\ * Correspondence: jgross@umn.edu
}

Received: 30 May 2020; Accepted: 22 June 2020; Published: 23 June 2020

check for updates

\begin{abstract}
Kura clover (Trifolium ambiguum) is a perennial living mulch species that can be used in conjunction with zone tillage to reduce nitrogen pollution, maintain ground cover, and provide nitrogen to crops. In such systems, kura clover is maintained between crop rows by limiting tillage only to within-row areas. However, the effect of zone-tilled living mulches on soil quality and nutrient cycling in these distinct regions is relatively unexplored. We examined three pools of labile soil organic matter (SOM): microbial biomass, particulate organic matter (POM), and permanganate oxidizable carbon (POXC). Soil samples were collected from both within-row and between-row locations of a zone-tilled kura clover living mulch at three time points per year: before spring zone tillage, approximately ten days after spring zone tillage and corn (Zea mays) planting, and at corn harvest in 2015 and 2016. In 2016, POM and POXC decreased within rows relative to between-row regions after tillage, suggesting that zone till management stimulated decomposition of readily available SOM to effectively localize nutrient cycling in this region and slow mineralization between rows where living kura clover remained. This work shows that zone-tilled living mulches may be a promising avenue for enhancing the synchrony of nutrient mineralization specifically within crop rows, while maintaining year-round ground cover between rows.
\end{abstract}

Keywords: living mulch; kura clover; organic agriculture; labile soil organic matter; microbial biomass; particulate organic matter; permanganate oxidizable carbon

\section{Introduction}

Maintaining living ground cover is a management practice known to reduce soil erosion and runoff, increase water infiltration, and build soil organic matter (SOM) [1,2]. Cover crops, defined as crops that are grown temporally or spatially between two cash crops in any given crop rotation [3], are gaining traction for their ability to contribute to these benefits. Moreover, leguminous cover crop varieties in particular can provide significant nitrogen $(\mathrm{N})$ contributions to subsequent crops [4-8].

Perennial cover crops, also known as living mulches (LMs), provide year-round soil coverage, an especially imperative task in the Upper Midwestern region of the United States (US) where landscapes are often left bare in the winter and spring, and thus are subject to soil losses and degradation [9]. Perennial root systems are known to allocate more net primary production belowground than annuals [10-12], in turn increasing soil microbial activity [13] and enhancing the formation of SOM [14]. Perennial roots also stabilize soil structure via the binding properties of root exudates $[15,16]$, mycorrhizal associations [17,18], and the creation of macropores [19]. 
One such LM species is kura clover (Trifolium ambiguum), a hardy perennial clover indigenous to the Caucasus region. Kura clover is well-suited for use in the Upper Midwestern US due to its unique tolerance to extreme cold [20]. Kura clover has been found to fix up to $155 \mathrm{~kg} \mathrm{~N} \mathrm{ha}^{-1}$ in Minnesota [21], and reduce agricultural externalities such as nitrate loading of water bodies [22,23]. More recent research has examined kura clover's effect on plant-available N [24-26] and maximized row crop production in this system via novel tillage methods $[25,27]$. Still, the effect of kura clover on soil quality in organic systems is largely unexplored.

Organic production systems may be improved with the use of kura clover due to the intersection of perennial legume benefits and the National Organic Program's mandated organic practices that call for improving soil biology and organic matter. In conventionally managed kura clover systems, zone tillage is combined with herbicides to annually clear within-row areas of aboveground kura clover biomass, where cash crops will be planted. However, because herbicides are prohibited in organic production, these systems instead must rely on mechanical zone tillage to create crop rows. While it is widely accepted that tillage has a detrimental effect on soil quality [28,29], it is unclear whether perennial vegetation incorporated through tillage will have an overriding, positive effect on soil quality despite tillage-induced carbon (C) oxidation. Assessing soil quality in organic kura clover systems may highlight the importance of the microbially-mediated nutrient cycling processes that are critical to organic agriculture.

Labile organic matter is a subset of SOM characterized as having a short turnover time due to its accessibility to microbes for mineralization [30]. Microbial biomass (MB) is itself one such pool that is known to increase under living plants [31] and under long-term reduced- or no-till management [32], where an abundance of organic materials are available to soil microbes for mineralization [33]. Particulate organic matter (POM) is another labile pool, which can be measured via density-fractionation to quantify labile SOM that generally contains plant and animal residues, fungal hyphae and residues, and root fragments [34]. These materials are uncomplexed and unprotected by or within soil particles, making them readily available for microbial decomposition [35]. A chemically labile SOM pool is permanganate oxidizable carbon (POXC), which is measured by quantifying the Coxidized by $\mathrm{KMnO}_{4}$, a strong oxidizing chemical used to mimic the oxidizing activity of soil microbes [36]. In an analysis of soil quality indicators, Morrow et al. [37] found that POXC ranked highest in terms of sensitivity to management practices, cost effectiveness, and sample turnaround time. Increases in POXC often occur in the absence of tillage [38,39], yet LM system effects on POXC have only recently been examined [24].

Our objective was to quantify labile SOM pools, including MB, POM, and POXC, in two distinct regions of a zone-tilled kura clover living mulch system: within rows, where kura clover was tilled and corn (Zea mays) planted, and between rows, where kura clover was perennially maintained.

\section{Materials and Methods}

\subsection{Site Description}

This experiment was established in 2015, following a previous year of zone-tilled soybean production, on a Waukegan silt loam (fine-silty over skeletal mixed, super active, mesic Typic Hapludoll) located at the University of Minnesota Rosemount Research and Outreach Center in Rosemount, MN, USA $\left(44^{\circ} 71^{\prime} \mathrm{N}, 93^{\circ} 7^{\prime} \mathrm{W}\right)$. Field history, preparation, operations, and weather are detailed in Ginakes et al. [25], where agronomic performance of kura clover for $\mathrm{N}$ cycling and organic corn production is discussed.

The field was planted to kura clover eight years prior to the experiment, and had been conventionally managed as a living mulch with either corn or soybean annually until spring of 2015 when organic management began. The experiment was relocated to an adjacent area in the same field in 2016, due to slug damage to clover after the 2015 harvest. The 2016 plot was also an eight-year stand of kura clover, except in the previous field season clover was used for forage production and not planted to a corn/soy cash crop. Additionally, field operations were later in 2016 
compared to 2015, particularly with regards to spring tillage and planting dates (4 and 5 May 2015 vs. 18 May 2016; [25]). Both differences in management resulted in a dramatically greater stand of kura clover in the second year.

Weather conditions likely also contributed to greater kura clover biomass in 2016 [25]. Briefly, spring and summer months in 2015 were cooler and wetter than the 30-year average. Notably, precipitation in July of 2015 was nearly double that of the 30-year average. On the other hand, temperatures in spring of 2016 were comparable to the 30 -year average $\left(<1^{\circ} \mathrm{C}\right.$ greater $)$, and precipitation was about one-third less. By summer months, temperatures remained comparable to the average, and precipitation much greater [25]. This experiment was part of a larger study arranged in a randomized complete block design that consisted of multiple tillage treatments [25]. For the present study, only one tillage treatment was used, wherein two soil sampling locations (within rows and between rows) and three repeated measures time points (pre-till, post-till, and harvest) were the factors of interest. This resulted in a two by three factorial randomized complete block design with four blocks. Because the study is within the context of a perennial living mulch system that had been maintained for eight years prior, using a non-living mulch control was not possible. As a surrogate negative control, we compared the annually zone-tilled, within-row region to the undisturbed region between crop rows where kura clover had not been tilled in the full eight-year span.

Plots were $9.1 \mathrm{~m}$ long and 6 rows wide; data were collected from the middle $6.1 \mathrm{~m}$ of the two center rows. Corn was planted as the cash crop at 79,000 seeds ha ${ }^{-1}$ on $76 \mathrm{~cm}$ rows prepared with a rotary zone till implement that was custom made by Northwest Tillers (Yakima, WA, USA). This implement created a $30 \mathrm{~cm}$ wide and $8 \mathrm{~cm}$ deep zone-tilled region from which within-row data were collected [27].

\subsection{Soil Sampling}

Soil was collected at the three specified time points in both 2015 and 2016, from within-row and between-row locations. Ten soil cores ( $32 \mathrm{~mm}$ diameter) were collected to a depth of $15 \mathrm{~cm}$, composited, homogenized, and sampled for analysis. Samples were stored in a cooler until returned to a $4{ }^{\circ} \mathrm{C}$ cooler for sample preparation. Labile SOM pools were measured as POXC, POM, and MB. Samples were divided in two; one subsample was dried at $35^{\circ} \mathrm{C}$ for at least $48 \mathrm{~h}$ before grinding and sieving to $2 \mathrm{~mm}$ to use for POXC and POM determinations, while the other was sieved to $2 \mathrm{~mm}$ and kept field-moist at $4{ }^{\circ} \mathrm{C}$ for $\mathrm{MB}$ quantification.

\subsection{Permanganate Oxidizable Carbon}

Permanganate oxidizable carbon was measured according to Weil et al. [36]. Briefly, $2.5 \mathrm{~g}$ of dry soil were added to $50 \mathrm{~mL}$ centrifuge tubes and $18 \mathrm{~mL}$ deionized water was added. Then, $2 \mathrm{~mL}$ of $\mathrm{KMnO}_{4}$ was added and shaken on a reciprocal shaker at $180 \mathrm{rpm}$ for exactly $2 \mathrm{~min}$. The samples were promptly removed and covered for exactly $10 \mathrm{~min}$, after which $0.5 \mathrm{~mL}$ supernatant was transferred to $49.5 \mathrm{~mL}$ deionized water. Final solutions were transferred to 96-well plates and measured on a spectrophotometer at $540 \mathrm{~nm}$. Absorbance was fitted to a standard curve, and calculated to determine C oxidation by $\mathrm{KMnO}_{4}$ reaction.

\subsection{Particulate Organic Matter}

Light-fraction (LF) POM was determined via density fractionation per Gregorich and Janzen [34]. Twenty grams dry soil was added to $250 \mathrm{~mL}$ high-density polyethylene bottles, and $40 \mathrm{~mL}$ sodium polytungstate $\left(\mathrm{Na}_{6}\left[\mathrm{H}_{2} \mathrm{~W}_{12} \mathrm{O}_{40}\right]\right)$ adjusted to $1.6 \mathrm{~g} \mathrm{~cm}^{-3}$ added. Bottles were shaken at $180 \mathrm{rpm}$ for $1 \mathrm{~h}$, swirled to remove particles from sides of bottles, and settled overnight. Bottles were centrifuged the following day at $5000 \mathrm{rpm}$ for $30 \mathrm{~min}$, carefully removed, and liquid was vacuum filtered through $1 \mu \mathrm{m}$ polycarbonate filters in filter flasks to separate POM. Filters holding POM were placed in tins and dried at $50^{\circ} \mathrm{C}$ overnight, after which the $\mathrm{POM}$ was ball ground to $<1 \mathrm{~mm}$ and measured for $\mathrm{C}$ and $\mathrm{N}$ on an Elementar VarioPYRO Cube (Elementar Americas, Ronkonkoma, NY, USA). 


\subsection{Microbial Biomass}

Microbial biomass was measured only in 2016 as an indicator of microbial activity, within two weeks of soil collection via a simulated chloroform slurry extraction [40]. Ten grams moist soil was weighed into two 70-mL test tubes. Each tube had $40 \mathrm{~mL} 0.5 \mathrm{M} \mathrm{K}_{2} \mathrm{SO}_{4}$ added; one was also fumigated by adding $0.5 \mathrm{~mL} \mathrm{CHCl} 3$. Tubes were shaken at $180 \mathrm{rpm}$ reciprocally for $4 \mathrm{~h}$, allowed to settle for at least $1 \mathrm{~h}$, and extracts were filtered carefully through \#42 Whatman paper, taking care not to pour off the bottom third of liquid where chloroform was assumed to have settled. Samples were frozen until analysis. Samples were analyzed on a Shimadzu TOC and TN analyzer (total organic carbon and total nitrogen, respectively; Kyoto, Japan), and final values were corrected for gravimetric soil moisture and calculated by subtracting unfumigated (baseline) from fumigated measurements.

\subsection{Statistical Analyses}

Statistical analyses were performed using the 'rstatix' package in RStudio [41,42]. Years were analyzed separately due to plot relocation within the same field in 2016. Data that did not meet assumptions of normality or equal variance were either inverse or $\log +1$ transformed. A mixed ANOVA was performed using soil location as a between-subjects factor and sampling time as a repeated measures, within-subjects factor. Where necessary, Greenhouse-Geisser corrections were used to satisfy assumptions of sphericity for sampling time. Significant interaction effects were further explored using Bonferroni-adjusted one-way models for simple main effects, followed by multiple pairwise comparisons when significant. Paired $t$-tests were used to examine the effect of time as a repeated measure. When no interaction was present, significant main effects were assessed with multiple pairwise comparisons, again using a Bonferroni adjustment and paired $t$-tests for sampling time effects.

All data are presented as untransformed, and are available in Supplementary Tables S1 and S2. Figures were generated using the 'ggplot2' package in RStudio [42,43].

\section{Results and Discussion}

\subsection{Permanganate Oxidizable Carbon}

In 2015, POXC data ranged from 607 to $706 \mathrm{mg} \mathrm{C} \mathrm{kg}^{-1}$ soil over the growing season, with no differences between sampling location or time. In 2016, POXC had a greater range, from 537 to $847 \mathrm{mg} \mathrm{C} \mathrm{kg}^{-1}$ soil, and there was an interactive effect of soil location and sampling time (Table 1; $p=0.06$ ). In particular, POXC was less between rows at harvest than either pre-till or post-till (Figure 1; $p=0.01$ and 0.02 , respectively). Within-row POXC showed an earlier decrease, with a $25 \%$ decrease after tillage $(p=0.038)$ and a $35 \%$ decrease by the harvest sampling time (Figure $1 ; p=0.021$ ).

Table 1. Analysis of variance for soil quality indicators by soil location, sampling time, and their interaction within experimental year.

\begin{tabular}{ccccccccc}
\hline & \multicolumn{3}{c}{$\mathbf{2 0 1 5}$} & \multicolumn{7}{c}{$\mathbf{2 0 1 6}$} \\
\cline { 2 - 9 } & POXC $^{\mathbf{1}}$ & POMC & POMN & POXC & POMC & POMN & MBC & MBN \\
\hline Fixed Effect & & \multicolumn{7}{c}{$p$-Value } \\
\hline Location & 0.549 & 0.14 & $\mathbf{0 . 0 8 4}$ & 0.153 & $\mathbf{0 . 0 2 7}$ & $\mathbf{0 . 0 0 4}$ & $\mathbf{0 . 0 0 5}$ & 0.741 \\
Time & 0.283 & $\mathbf{0 . 0 3 9 ^ { 2 }}$ & $\mathbf{0 . 0 3 4}$ & $<\mathbf{0 . 0 0 1}$ & 0.108 & $<\mathbf{0 . 0 0 1}$ & 0.209 & $\mathbf{0 . 0 5 6}$ \\
Location $\times$ Time & 0.243 & 0.578 & 0.231 & $\mathbf{0 . 0 6}$ & $\mathbf{0 . 0 5}$ & $\mathbf{0 . 0 2 4}$ & 0.553 & 0.61 \\
\hline
\end{tabular}

${ }^{1}$ POXC: permanganate oxidizable carbon; POMC: particulate organic matter carbon; POMN: particulate organic matter nitrogen; MBC: microbial biomass carbon; MBN: microbial biomass nitrogen; ${ }^{2}$ bold indicates significance at $p<0.1$. 


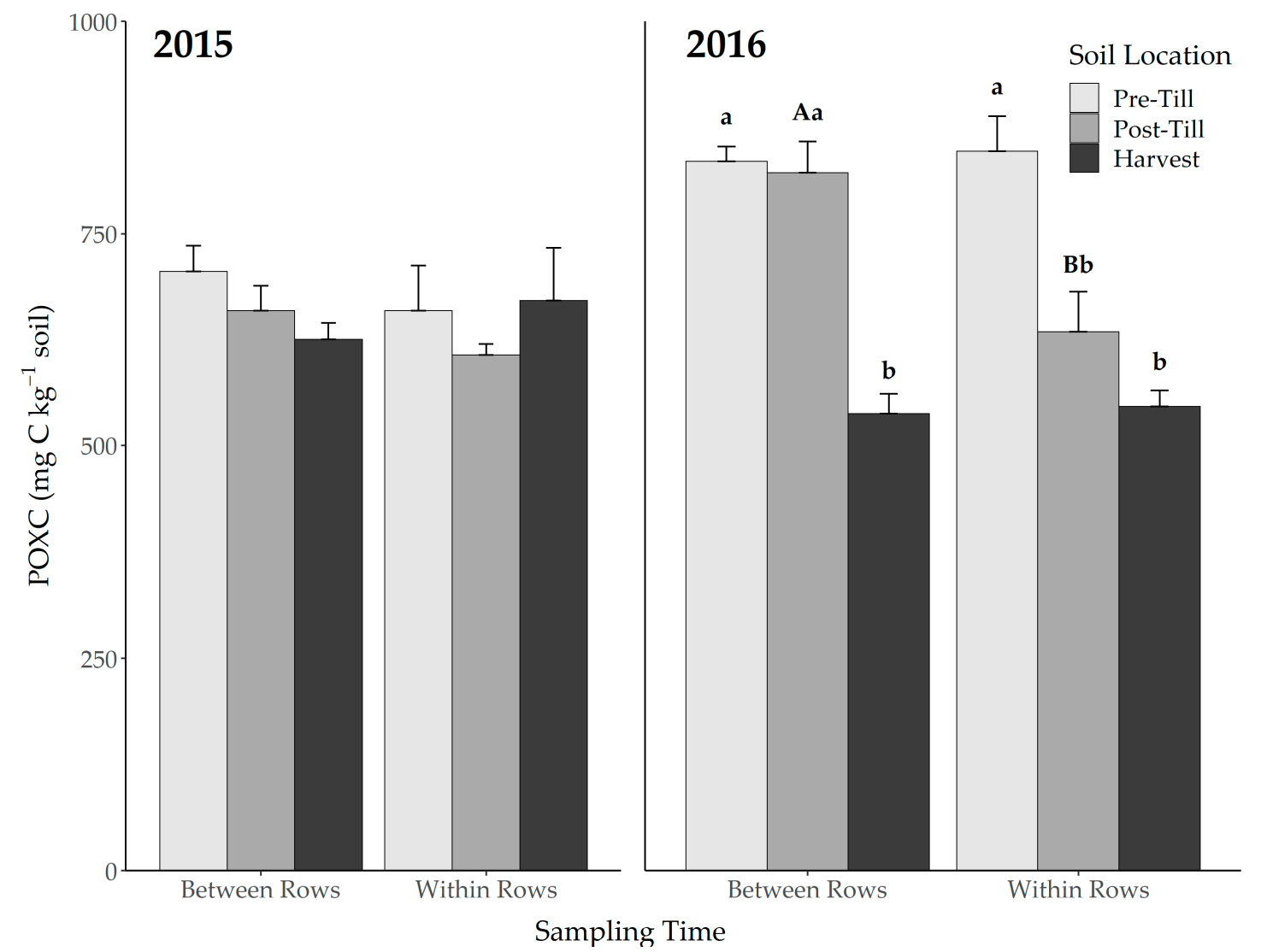

Figure 1. Effect of soil location and sampling time on permanganate oxidizable carbon (POXC) in 2015 and 2016. Error bars represent one standard error. Different capital letters over bars represent a significant difference between soil locations within time point $(p<0.05)$, while different lowercase letters over bars represent a significant difference between sampling times within soil locations $(p<0.05)$.

Moreover, tillage was associated with a 22\% decrease in within-row POXC in 2016 (Figure 1; $p=0.021$ ), when kura clover biomass was approximately 10.5 times greater at tillage than in 2015 (2253 and $213 \mathrm{~kg} \mathrm{ha}^{-1}$, respectively; [25]). The 2015 plot had been in zone-tilled row crop production for eight years prior to the experiment, with highly-tilled within-row areas remaining constant and clover regrowth limited within this zone, while the area used in 2016 had been in forage production for the prior season. This suggests that while overall POXC flux may otherwise have been similar for within-row and between-row areas, tillage hastened labile carbon oxidation within rows such that, coupled with kura clover residue mineralization, $\mathrm{N}$ was synchronously provisioned to the crop [24,25].

Permanganate oxidizable $C$ is generally understood to represent a relatively processed labile SOM pool [38]. It is known to decrease with soil disturbance via tillage [44,45], while conservation tillage $[46,47]$ and the addition of C-rich organic amendments [48] increase POXC. Our findings show that the combination of tillage and the high-quality kura clover aboveground biomass incorporation at termination may have driven decreases in POXC within crop rows following tillage (Figure 1). Warmer temperatures in 2016 likely also played a role in greater C oxidation. This decrease in POXC following kura clover incorporation within crop rows may have been driven by kura clover's high $\mathrm{N}$ content, leading to rapid N mineralization and availability [25] and a coupled oxidation of POXC.

\subsection{Microbial Biomass and Particulate Organic Matter}

Soil location contributed to differences in microbial biomass carbon (MBC; Table 1), where quantities were greater between rows than within rows across all sampling times $(p=0.082$; Figure 2$)$. This effect was not significant for corresponding microbial biomass nitrogen (MBN) results $(p=0.651)$. Despite a significant effect of time on MBN (Table 1), pairwise comparisons between sampling times showed 
no significant differences between them. This was likely due to high variability, particularly at the post-till sampling time where there was greater MBN within rows than before tillage by a factor of 2.9 $(p=0.122 ;$ Figure 2).

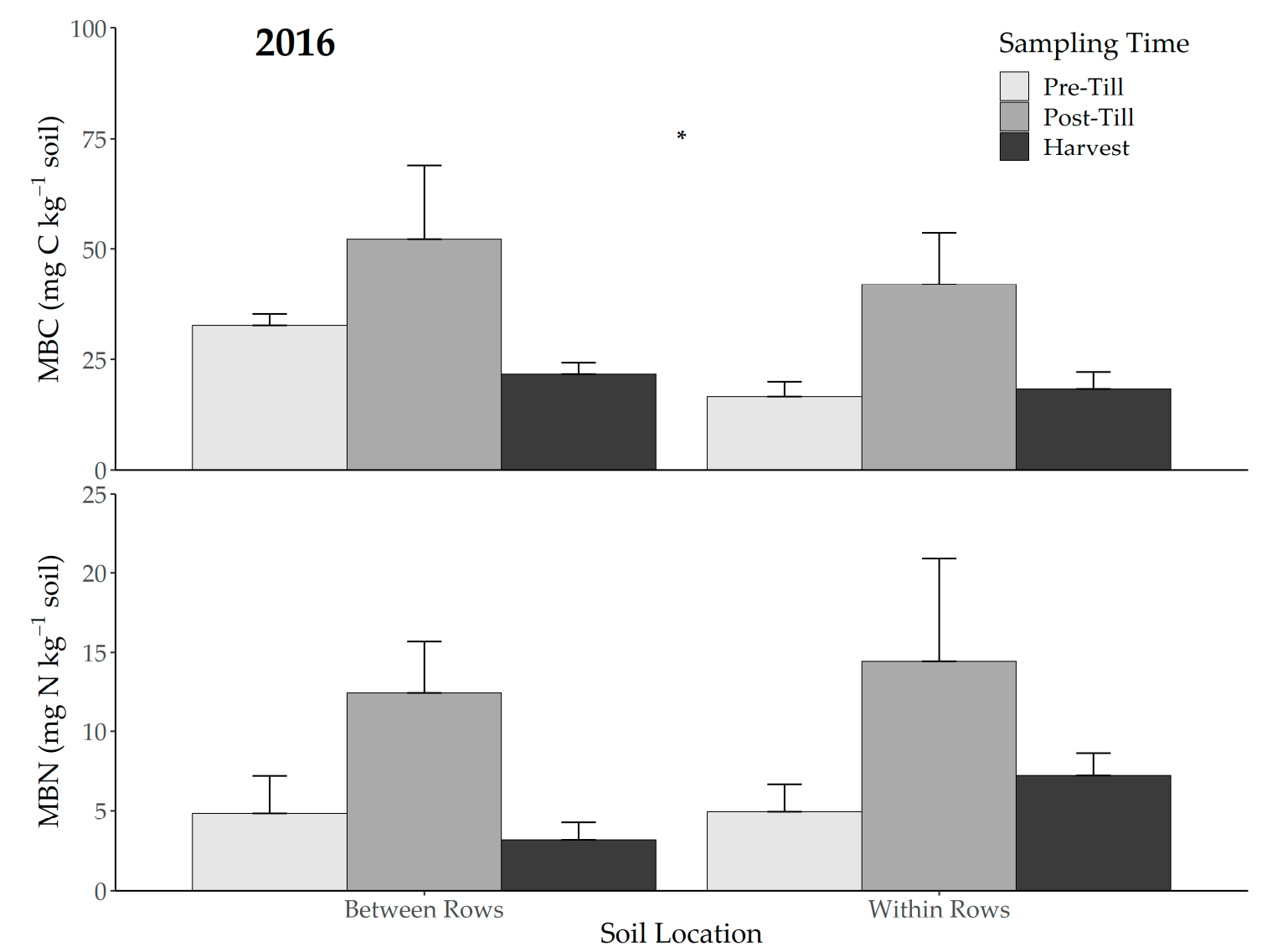

Figure 2. Effect of soil location and sampling time on microbial biomass carbon and nitrogen (MBC and MBN, respectively) in 2016. Error bars represent one standard error. Asterisks represent a difference between soil locations across sampling time $(p<0.1)$.

Particulate organic matter trends were similar to those of POXC. Across years, POM carbon and nitrogen (POMC and POMN, respectively) ranged from 702 to 1508 and 56 to $144 \mathrm{mg} \mathrm{kg} \mathrm{soil}{ }^{-1}$. In 2015, sampling time contributed to variation in both POMC and POMN ( $p=0.039$ and 0.034 , respectively), while soil location was weakly associated with differences only in POMN ( $p=0.084$; Table 1). Particulate organic matter $C$ followed a similar trend, but with greater variability and thus was not significant. Pairwise comparisons showed that across sampling times, between-row regions had $25 \%$ greater POMN than within crop rows ( $p=0.045$; Figure 3$)$. Differences were more apparent in 2016, with interactive effects of soil location and sampling time for both POMC and POMN $(p=0.05$ and 0.024 respectively; Table 1$)$. Spring tillage was associated with POMC and POMN reductions, such that within-row regions had approximately half the POM of between-row regions after tillage ( $p=0.007$ and $<0.001$, respectively; Figure 3). Sampling time also affected POMN within soil location, where between-row POMN was reduced by the harvest time point, while within-row areas were reduced by the post-till sampling time (Figure 3). These interactive rankings match those of POXC in the same year (Figure 1), reinforcing the indication that zone tillage localized more timely SOM decomposition within rows when delayed planting and warmer temperatures resulted in the incorporation of ample clover biomass. Mirsky et al. [49] have demonstrated comparable responses to management effects for POXC and POM. 


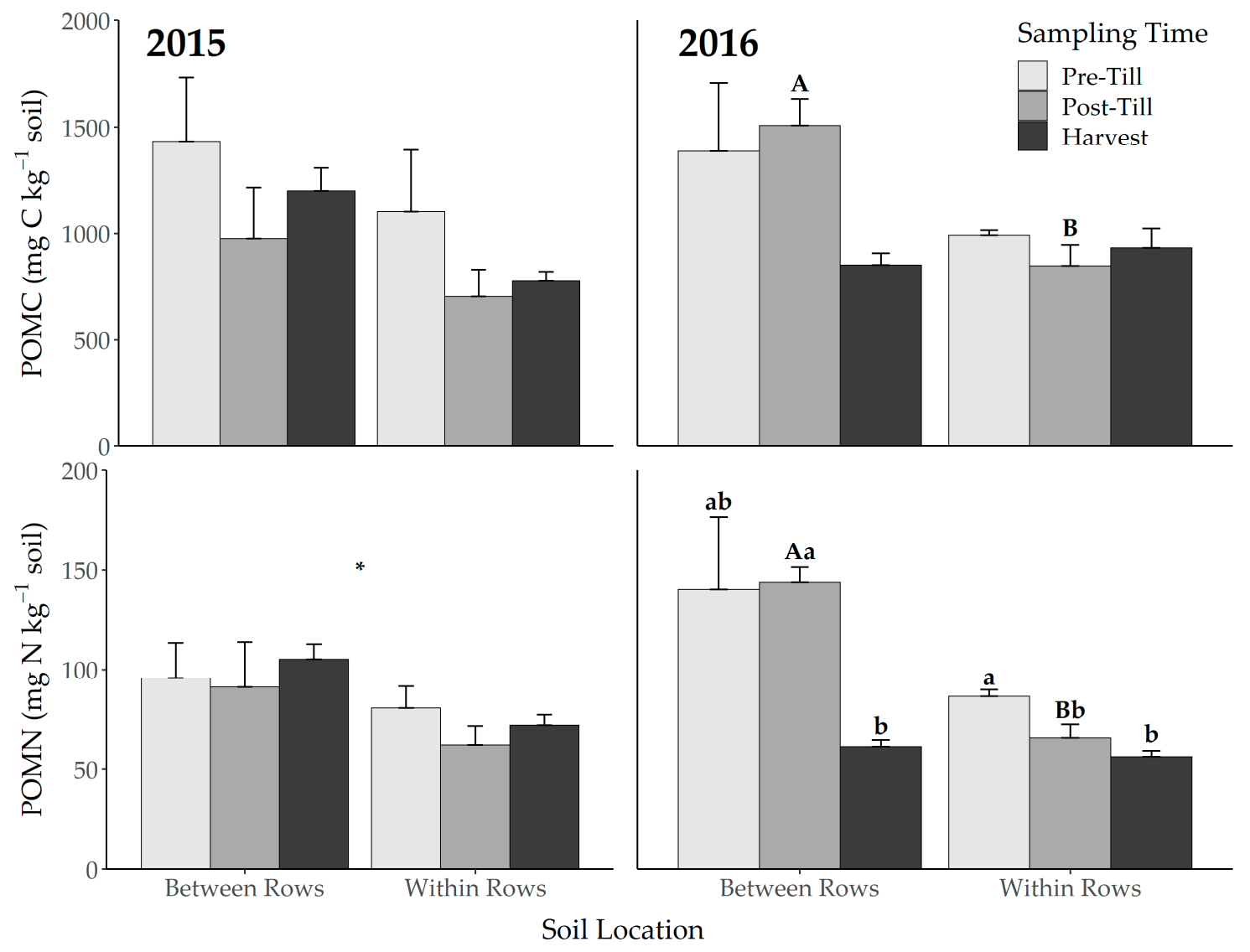

Figure 3. Effect of soil location and sampling time on particulate organic matter carbon and nitrogen (POMC and POMN, respectively) in 2015 and 2016. Error bars represent one standard error. Asterisks represent a difference between soil locations across time points $(p<0.05)$. Different capital letters over bars represent a significant difference between soil locations within time point $(p<0.01)$, while different lowercase letters over bars represent a significant difference between sampling times within soil locations $(p<0.1)$.

Particulate organic matter derived from a perennial kura clover LM may be comprised of dead and sloughed roots [50], as well as aboveground material incorporated through tillage, in varying stages of decay. Diochon et al. [51] found that light-fraction POM C:N ratios decreased over time. The relatively low POM C:N in our results (approximately 12) suggests that detected POM may have been supplied by older, relatively decomposed root materials rather than newly incorporated shoot material. It is likely that, similar to POXC, zone tillage stimulated POM oxidation by adding high-quality aboveground kura clover residue. This supports findings from Ginakes et al. [25], where soil inorganic N was 30.7 and $19.4 \mathrm{mg} \mathrm{N} \mathrm{kg}^{-1}$ soil post-tillage for within- and between-row areas respectively. This relationship between POM and N mineralization has also been established by St. Luce et al. [52], who reported a correlation coefficient between POMN and soil $\mathrm{N}$ mineralization of $\mathrm{R}^{2}=0.54$. Overall, the results suggest that zone tillage, particularly when used to incorporate labile legume shoots, may drive mineralization of labile SOM pools and potentially supply nearby crops with plant-available N.

\section{Conclusions}

Results from this study suggest that zone-tilled living mulches can facilitate nutrient cycling within rows where soil is tilled in preparation for crop planting, while slowing nutrient turnover between crop rows where the living mulch is maintained. In the second year of our study, warmer spring temperatures, clover management for forage production in the prior year, and a later planting date resulted in relatively great kura clover spring biomass. Accordingly, POXC and POM pools decreased 
more rapidly within rows after spring tillage compared to between-row regions. Results indicate that zone tillage may offer greater $\mathrm{N}$ provisioning benefits to crops with delayed planting or when following one or more years of kura clover forage production or rest. Results also suggest that living mulch root systems can greatly influence soil quality, as between-row regions in our experiment had been maintained for eight years prior with no incorporation of aboveground biomass to enhance SOM pools. Further work to quantify the extent to which above- and belowground biomass contributes to nutrient cycling and soil building processes in such systems would be a valuable tool for navigating management options.

Supplementary Materials: The following are available online at http://www.mdpi.com/2077-0472/10/6/243/s1, Table S1: Data, Table S2: ReadMe file.

Author Contributions: Conceptualization, P.G., J.M.G., J.M.B.; methodology, P.G., J.M.G., J.M.B., T.S.-n.; validation, P.G.; formal analysis, P.G.; investigation, P.G., J.M.G., J.M.B., T.S.-n.; resources, J.M.G., J.M.B.; data curation, P.G.; writing—original draft preparation, P.G.; writing—review and editing, P.G., J.M.G., J.M.B., T.S.-n.; visualization, P.G., T.S.-n.; supervision, J.M.G., J.M.B.; project administration, P.G., J.M.G., J.M.B.; funding acquisition, J.M.G., J.M.B. All authors have read and agreed to the published version of the manuscript.

Funding: This research was funded by Minnesota Department of Agriculture (Water Quality grant \#76922), Ceres Trust, and the North Central Region Sustainable Agriculture Research and Education (grant GNC14-187).

Acknowledgments: We are sincerely grateful for the assistance of Michelle Dobbratz, Victoria Hoeppner, Elayna Shapiro, Lindsay Countryman, Yordanose Solomone, Victoria Hoffman, Rachel Brann, Bruna De Bacco Lopes, and Kaleiilima Holt in this project. We also thank two anonymous reviewers for their constructive comments.

Conflicts of Interest: The authors declare no conflicts of interest.

\section{References}

1. Joyce, B.A.; Wallender, W.W.; Mitchell, J.P.; Huyck, L.M.; Temple, S.R.; Brostrom, P.N.; Hsiao, T.C. Infiltration and soil water storage under winter cover cropping in California's Sacramento Valley. Trans. ASAE 2002, 45, 315-326. [CrossRef]

2. Grabber, J.H.; Jokela, W.E. Off-season groundcover and runoff characteristics of perennial clover and annual grass companion crops for no-till corn fertilized with manure. J. Soil Water Conserv. 2013, 68, 411-418. [CrossRef]

3. Bodner, G.; Himmelbauer, M.; Loiskandl, W.; Kaul, H.P. Improved evaluation of cover crop species by growth and root factors. Agron. Sustain. Dev. 2010, 30, 455-464. [CrossRef]

4. Parr, M.; Grossman, J.M.; Reberg-Horton, S.C.; Brinton, C.; Crozier, C. Nitrogen Delivery from Legume Cover Crops in No-Till Organic Corn Production. Agron. J. 2011, 103, 1578-1590. [CrossRef]

5. Wayman, S.; Cogger, C.; Benedict, C.; Burke, I.; Collins, D.; Bary, A. The influence of cover crop variety, termination timing and termination method on mulch, weed cover and soil nitrate in reduced-tillage organic systems. Renew. Agric. Food Syst. 2014, 30, 450-460. [CrossRef]

6. Jani, A.D.; Grossman, J.; Smyth, T.J.; Hu, S. Winter legume cover-crop root decomposition and N release dynamics under disking and roller-crimping termination approaches. Renew. Agric. Food Syst. 2015, 31, 214-229. [CrossRef]

7. Liebman, A.M.; Grossman, J.; Brown, M.; Wells, M.S.; Reberg-Horton, S.C.; Shi, W. Legume cover crops and tillage impact nitrogen dynamics in organic corn production. Agron. J. 2018, 110, 1046-1057. [CrossRef]

8. Ali, S.A.; Tedone, L.; Verdini, L.; Cazzato, E.; De Mastro, G. Wheat response to no-tillage and nitrogen fertilization in a long-term faba bean-based rotation. Agronomy 2019, 9, 50. [CrossRef]

9. Ochsner, T.E.; Albrecht, K.A.; Schumacher, T.W.; Baker, J.M.; Berkevich, R.J. Water Balance and Nitrate Leaching under Corn in Kura Clover Living Mulch. Agron. J. 2010, 102, 1169-1178. [CrossRef]

10. Goudriaan, J.; Groot, J.J.R.; Uithol, P.W.J. Productivity of Agro-ecosystems. In Terrestrial Global Productivity; Roy, J., Saugier, B., Mooney, H.A., Eds.; Academic Press: San Diego, CA, USA, 2001; pp. 301-313.

11. Saugier, B.; Roy, J.; Mooney, H.A. Estimations of Global Terrestrial Productivity. In Terrestrial Global Productivity; Roy, J., Saugier, B., Mooney, H.A., Eds.; Academic Press: San Diego, CA, USA, 2001; pp. 543-557.

12. Yacobi, Y.Z.; Erez, J.; Hadas, O. Primary production. In Aquatic Ecology; Whalen, J.K., Sampedro, L., Eds.; CAB International: Wallingford, UK, 2014; Volume 6, pp. 417-438. 
13. Duda, G.P.; Guerra, J.G.M.; Monteiro, M.T.; De-Polli, H.; Teixeira, M.G. Perennial herbaceous legumes as live soil mulches and their effects on C, N and P of the microbial biomass. Sci. Agric. 2003, 60, $139-147$. [CrossRef]

14. Schmidt, M.W.I.; Torn, M.S.; Abiven, S.; Dittmar, T.; Guggenberger, G.; Janssens, I.A.; Kleber, M.; Kögel-Knabner, I.; Lehmann, J.; Manning, D.A.C.; et al. Persistence of soil organic matter as an ecosystem property. Nature 2011, 478, 49-56. [CrossRef]

15. Bronick, C.J.; Lal, R. Soil structure and management: A review. Geoderma 2005, 124, 3-22. [CrossRef]

16. Bardgett, R.D.; Mommer, L.; De Vries, F.T. Going underground: Root traits as drivers of ecosystem processes. Trends Ecol. Evol. 2014, 29, 692-699. [CrossRef] [PubMed]

17. Dabney, S.M.; Delgado, J.A.; Reeves, D.W. Using winter cover crops to improve soil and water quality. Commun. Soil Sci. Plant. Anal. 2001, 32, 1221-1250. [CrossRef]

18. Kabir, Z.; Koide, R.T. Effect of autumn and winter mycorrhizal cover crops on soil properties, nutrient uptake and yield of sweet corn in Pennsylvania, USA. Plant. Soil 2002, 238, 205-215. [CrossRef]

19. Ghestem, M.; Sidle, R.C.; Stokes, A. The Influence of Plant Root Systems on Subsurface Flow: Implications for Slope Stability. Bioscience 2011, 61, 869-879. [CrossRef]

20. Sheaffer, C.C.; Marten, G.C. Kura clover forage yield, forage quality, and stand dynamics. Can. J. Plant. Sci. 1991, 71, 1169-1172. [CrossRef]

21. Seguin, P.; Russelle, M.P.; Sheaffer, C.C.; Ehlke, N.J.; Graham, P.H. Dinitrogen fixation in kura clover and birdsfoot trefoil. Agron. J. 2000, 92, 1216-1220. [CrossRef]

22. Qi, Z.; Helmers, M.J.; Kaleita, A.L. Soil water dynamics under various agricultural land covers on a subsurface drained field in north-central Iowa, USA. Agric. Water Manag. 2011, 98, 665-674. [CrossRef]

23. Siller, A.R.S.; Albrecht, K.A.; Jokela, W.E. Soil Erosion and Nutrient Runoff in Corn Silage Production with Kura Clover Living Mulch and Winter Rye. Agron. J. 2016, 108, 989-999. [CrossRef]

24. Ginakes, P.; Grossman, J.M.; Baker, J.M.; Dobbratz, M.; Sooksa-nguan, T. Soil carbon and nitrogen dynamics under zone tillage of varying intensities in a kura clover living mulch system. Soil Tillage Res. 2018, 184, 310-316. [CrossRef]

25. Ginakes, P.; Grossman, J.; Baker, J.; Sooksa-nguan, T. Tillage intensity influences nitrogen cycling in organic kura clover living mulch. Nutr. Cycl. Agroecosystems 2020, 116, 71-82. [CrossRef]

26. Alexander, J.R.; Venterea, R.T.; Baker, J.M.; Coulter, J.A. Kura clover living mulch: Spring management effects on nitrogen. Agronomy 2019, 9, 69. [CrossRef]

27. Dobbratz, M.; Baker, J.M.; Grossman, J.; Wells, M.S.; Ginakes, P. Rotary zone tillage improves corn establishment in a kura clover living mulch. Soil Tillage Res. 2019, 189, 229-235. [CrossRef]

28. Alvarez, R. A review of nitrogen fertilizer and conservation tillage effects on soil organic carbon storage. Soil Use Manag. 2005, 21, 38-52. [CrossRef]

29. Mikha, M.M.; Vigil, M.F.; Benjamin, J.G. Long-Term Tillage Impacts on Soil Aggregation and Carbon Dynamics under Wheat-Fallow in the Central Great Plains. Soil Sci. Soc. Am. J. 2013, 77, 594-605. [CrossRef]

30. Ladd, J.N.; Oades, J.M.; Amato, M. Microbial biomass formed from 14 C, 15 N-labelled plant material decomposing in soils in the field. Soil Biol. Biochem. 1981, 13, 119-126. [CrossRef]

31. Zhu, B.; Gutknecht, J.L.M.; Herman, D.J.; Keck, D.C.; Firestone, M.K.; Cheng, W. Rhizosphere priming effects on soil carbon and nitrogen mineralization. Soil Biol. Biochem. 2014, 76, 183-192. [CrossRef]

32. Larsen, E.; Grossman, J.; Edgell, J.; Hoyt, G.; Osmond, D.; Hu, S. Soil biological properties, soil losses and corn yield in long-term organic and conventional farming systems. Soil Tillage Res. 2014, 139, 37-45. [CrossRef]

33. Plaza, C.; Courtier-Murias, D.; Fernández, J.M.; Polo, A.; Simpson, A.J. Physical, chemical, and biochemical mechanisms of soil organic matter stabilization under conservation tillage systems: A central role for microbes and microbial by-products in C sequestration. Soil Biol. Biochem. 2013, 57, 124-134. [CrossRef]

34. Gregorich, E.G.; Janzen, H.H. Storage of soil carbon in the light fraction and macroorganic matter. In Structure and organic matter storage in agricultural soils; Carter, M.R., Stewart, M.A., Eds.; CRC Press: New York, NY, USA, 1996; pp. 167-190.

35. Christensen, B.T. Physical fractionation of soil and structural and functional complexity in organic matter turnover. Eur. J. Soil Sci. 2001, 52, 345-353. [CrossRef]

36. Weil, R.R.; Islam, K.R.; Stine, M.A.; Gruver, J.B.; Samson-Liebig, S.E. Estimating active carbon for soil quality assessment: A simplified method for laboratory and field use. Am. J. Altern. Agric. 2003, 18, 3-17. 
37. Morrow, J.G.; Huggins, D.R.; Carpenter-Boggs, L.A.; Reganold, J.P. Evaluating measures to assess soil health in long-term agroecosystem trials. Soil Sci. Soc. Am. J. 2016, 80, 450-462. [CrossRef]

38. Culman, S.W.; Snapp, S.S.; Freeman, M.A.; Schipanski, M.E.; Beniston, J.; Lal, R.; Drinkwater, L.E.; Franzluebbers, A.J.; Glover, J.D.; Grandy, A.S.; et al. Permanganate oxidizable carbon reflects a processed soil fraction that is sensitive to management. Soil Sci. Soc. Am. J. 2012, 76, 494-504. [CrossRef]

39. Awale, R.; Chatterjee, A.; Franzen, D. Tillage and N-fertilizer influences on selected organic carbon fractions in a North Dakota silty clay soil. Soil Tillage Res. 2013, 134, 213-222. [CrossRef]

40. Fierer, N.; Schimel, J.P.; Holden, P.A. Variations in microbial community composition through two soil depth profiles. Soil Biol. Biochem. 2003, 35, 167-176. [CrossRef]

41. Kassambara, A. rstatix: Pipe-Friendly Framework for Basic Statistical Tests. 2020.

42. R Core Team. R: A Language and Environment for Statistical Computing. 2018.

43. Wickham, H. ggplot2: Elegant Graphics for Data Analysis. 2016.

44. Panettieri, M.; Knicker, H.; Berns, A.E.; Murillo, J.M.; Madejón, E. Moldboard plowing effects on soil aggregation and soil organic matter quality assessed by 13C CPMAS NMR and biochemical analyses. Agric. Ecosyst. Environ. 2013, 177, 48-57. [CrossRef]

45. Plaza-Bonilla, D.; Álvaro-Fuentes, J.; Cantero-Martínez, C. Identifying soil organic carbon fractions sensitive to agricultural management practices. Soil Tillage Res. 2014, 139, 19-22. [CrossRef]

46. Melero, S.; López-Garrido, R.; Madejón, E.; Murillo, J.M.; Vanderlinden, K.; Ordóñez, R.; Moreno, F. Long-term effects of conservation tillage on organic fractions in two soils in southwest of Spain. Agric. Ecosyst. Environ. 2009, 133, 68-74. [CrossRef]

47. Lewis, D.B.; Kaye, J.P.; Jabbour, R.; Barbercheck, M.E. Labile carbon and other soil quality indicators in two tillage systems during transition to organic agriculture. Renew. Agric. Food Syst. 2011, 26, 342-353. [CrossRef]

48. Spargo, J.T.; Cavigelli, M.A.; Mirsky, S.B.; Maul, J.E.; Meisinger, J.J. Mineralizable soil nitrogen and labile soil organic matter in diverse long-term cropping systems. Nutr. Cycl. Agroecosystems 2011, 90, 253-266. [CrossRef]

49. Mirsky, S.B.; Lanyon, L.E.; Needelman, B.A. Evaluating Soil Management Using Particulate and Chemically Labile Soil Organic Matter Fractions. Soil Sci. Soc. Am. J. 2008, 72, 180-185. [CrossRef]

50. De Neergaard, A.; Gorissen, A. Carbon allocation to roots, rhizodeposits and soil after pulse labelling: A comparison of white clover (Trifolium repens L.) and perennial ryegrass (Lolium perenne L.). Biol. Fertil. Soils 2004, 39, 228-234. [CrossRef]

51. Diochon, A.; Gillespie, A.W.; Ellert, B.H.; Janzen, H.H.; Gregorich, E.G. Recovery and dynamics of decomposing plant residue in soil: An evaluation of three fractionation methods. Eur. J. Soil Sci. 2016, 67, 196-205. [CrossRef]

52. St. Luce, M.; Whalen, J.K.; Ziadi, N.; Zebarth, B.J. Net nitrogen mineralization enhanced with the addition of nitrogen-rich particulate organic matter. Geoderma 2016, 262, 112-118. [CrossRef] 